\title{
ALLELOPATHIC ACTIVITY OF SOME DESERT PLANTS AGAINST PLANT PATHOGENIC BACTERIA AND NEMATODES
}

\author{
Abdel-Rahman, A. G. ${ }^{(1)}$; Hashem, Hanan, A. ${ }^{(2)}$; Kassem, Hala, A. ${ }^{(3)}$ \\ and Abdel Aziz, Nehad, F. ${ }^{(1)}$ \\ 1) Plant Protection Department, Desert Research Center, El- Matariya, Cairo \\ 2) Botany Departement, Faculty of Science, Ain Shams University \\ 3) Environmental Basic Sciences Departement, Institute of Environmental \\ Studies and Research, Ain Shams University.
}

\begin{abstract}
The extensive use of chemicals in plant protection has given rise to concerns about pesticide residues in the environment and to the development of pesticide-resistance by any organisms. Allelopathic plants offer better alternative for this purpose due to being cost-saving, eco-friendly, easy to use, efficient and safe. So, the present work was carried out to evaluate the allelopathic effect of three desert plants (Artemisia judaica, Asphodelus microcarpus, Solanum nigrum) on root knot nematode (Meloidogyne incognita) and three gram negative pathogenic bacterial strains (Erwinia carotovora, Xanthomonas campestris and Ralestonia solanacearum) using root exudates and leaf extracts of each plant with different concentrations. Under laboratory conditions, the data indicated that the three plants contain nematicidal compounds; the inhibitory effect was proportional to the concentrations used. Artemisia judaica extract showed the highest level $(100 \%)$ of nematicidal activity and indicated good antibacterial activities against all the tested bacterial strains also recorded the best result of minimum inhibitory concentration followed by A.microcarpus root exudate. While the root exudate of A.judaica, S. nigrum had no antibacterial activity, leaf extracts of $S$. nigrum had weak antibacterial activity. Aqueous leaf extracts of A.judaica appears to be attractive for the development of nematicidal and bactericidal bio- pesticides.
\end{abstract}

Key words: Allelopathy, desert plants, leaf extracts, root exudates, root knot nematode, bacteria. 
J. Environ. Sci.

Institute of Environmental Studies and Research - Ain Shams University

\section{INTRODUCTION}

Biological control of plant diseases and plant pathogens is highly significant in agricultural field. There is great stimulant to discover biologically active natural products from higher plants to act as herbicides, fungicides, bactericides, nematicides and insecticides that are better than synthetic agrochemicals and are much safer, from a health and environmental point-of view. Allelopathy thus offers an attractive environmentally friendly alternative to pesticides in agricultural pest management (Inderjit and Mukerji, 2006). In 1996, the International Allelopathy Society presented its definition of allelopathy to refer to any process involving secondary metabolites produced by plants, microorganisms, viruses and fungi that influence the growth and development of agricultural and biological systems (Cheng and Cheng, 2015).Incorporating allelopathy into agricultural management systems may reduce the use of pesticides, decrease environment/soil pollution, and diminish auto toxicity dangers, increase crop growth and productivity enhancement (Sodaeizadeh and Hosseini, 2012).

Root knot nematode is plant-parasitic nematodes which attack plants and cause crop losses annually in fruit crops and vegetable production. Meloidogyne spp. being the most common and widespread group of root knot nematodes in the world (Jones et al.,2013) which cause weak growth, poor yield, and low quality and can break the resistance of host plant and expose them to other pathogens and diseases. (Aissani et al., 2013)Among the huge diversity of plant pathogens, which include viruses, bacteria, fungi, nematodes, and insects, roughly 150 are bacterial species that cause diseases 
to plants which restrict the crop production and record annual crop losses in all countries. Use of agrochemicals to control bacterial diseases is not promising because of the high risk of its high toxic residues (Kannan and Bastas, 2015).The future looks bright for identifying new classes of pesticides (cheap and safe) from natural plant extracts and root exudates to replace the synthetic harmful and expensive chemicals used in the control of these pests at present (Danahap and Wonang 2016).

The objective of the present work was to evaluate the allelopathic potential of compounds contained in leaf extracts and root exudates of three desert plants against root-knot nematode $M$. incognita and three plant pathogenic gram negative bacteria.

\section{MATERIALS AND METHODS}

\section{Collection of plant materials}

Plant samples were collected as follow:

1. Wild onion, Asphodelus microcarpus (family, Liliaceae) and black night shade, Solanum nigrum (family, Solanaceae) from the North western coast of Egypt.

2. Worm wood, Artemisia judaica (family, Asteraceae) was collected from Saint Catherine, Sinai, Egypt.

Samples from each plant were then classified to roots and vegetative parts to obtain the root exudates, the aqueous leaf extract and the decayed residue of each plant. 


\section{Extraction of root exudates and plant leaves of the tested plants}

According to Lu et al., (2015), the collection of allelopathic chemicals from the undisturbed plant root system was difficult because of their low concentrations and the high level of contaminants in the soil. Asphodelus microcarpus was collected and transported to the laboratory at the Plant Protection Department, Desert Research Center, for sterilization and collection of root exudates (Tang and Young, 1982; Balah, 2015) Onion bulbs were used for germination as it was very difficult to use its seeds in germination under laboratory conditions. Solanum nigrum and Artemisia judaica seeds were germinated using tissue culture technique which proved to be the best way to obtain the secondary metabolites using MS basal hormone free media (Murashige and Skoog, 1962; Wu et al., 2000).Root exudates were then collected from 400 seedlings grown on MS liquid media and centrifuged at $5000 \mathrm{rpm}$ for $10 \mathrm{~min}$ to remove any cellular debris, $\mathrm{pH}$ was adjusted at $\mathrm{pH} \leq 4$, root exudates supernatant was extracted by adding ethyl acetate (added 3 times), exudates were concentrated to dryness by aeration then dissolved in ethanol (constant volume) to prepare 25, 50, 75 and $100 \mu \mathrm{g} \mathrm{ml}{ }^{-1}$ concentrations (Balah 2015; Dangash et al., 2015). Aqueous extraction from leaves of the three plants was carried out according to (Balah and Nassar, 2011.) 


\section{Evaluation of allelochemicals pesticidal activity:}

In this experiment, pure culture of juveniles 2(J2) root knot nematode Meloidogyne incognita were used. In addition, three species of bacteria namely (Erwinia carotovora, Xanthomonas campestrisand Ralestonia solanacearum) were used.

\subsection{Nematicidal activity}

\section{A. Hatchability assay:}

Eggs of $M$. incognita were collected from heavily infected tomato roots, three egg-masses of almost equal size (each mass contains 350 eggs approximately) Eggs were washed by rinsing with tap water through a 200 mesh (75 pm) sieve, collected on a 450 meshsieve and transferred into distilled water forming egg suspension (Hussey and Barker, 1973). One $\mathrm{ml}$ of egg suspension was placed in the petri plate and eggs were counted under the stereoscope. (40-55 eggs $/ \mathrm{ml}$ ) and $1 \mathrm{ml}$ of each of the root exudates or leaves extracts were transferred in 5-cm-diameter petri dishes and were maintained at $25^{\circ} \mathrm{C} .1 \mathrm{ml}$ egg suspension and $1 \mathrm{ml}$ distilled water served as control. After four days of exposure, the number of hatched eggs was counted under a low power stereomicroscope. Each treatment was replicated three times. The toxicity of allelochemicals was assessed as the mean percentage of the hatched eggs (Kayani et al., 2001). Hatchability inhibition (HI)was calculated from the formula

$\mathrm{HI} \%=[(\mathrm{C}-\mathrm{T}) / \mathrm{C}] \times 100$ where $\mathrm{C}$ is the number of hatching control and $\mathrm{T}$ is number of hatching after treatment. Lethal concentrations were calculated using probit analysis according to Finney (1971). 
B. Larvicidal assay:

Pure culture of $\mathrm{J} 2$ root knot nematode $M$. incognita was obtained from tomato plants. Different concentrations of allelochemicals were prepared. Two- $\mathrm{ml}$ of each concentration was transferred to $5 \mathrm{~cm}$ diameter petri dishes into which $0.1 \mathrm{ml}$ of freshly hatched larval suspension containing 50 Juveniles was added. Juveniles kept in sterilized distilled water were used as controls. Each treatment was replicated three times and the dishes were kept in an incubator $\left(27 \pm 2^{\circ} \mathrm{C}\right)$. Mortality of juveniles was recorded after $24 \mathrm{~h}$ of exposure. The nematodes were considered dead if they did not move when probed with a fine needle (Akyazi, 2014). The percentages of mortality were corrected according to Abbott, (1925). Lethal concentration $\left(\mathrm{LC}_{50}\right)$ was calculated through probit analysis (Finney, 1971).

\subsection{Bactericidal activity}

The estimation of bactericidal activity of plant allelochemicals was carried out according to agar well method (Cooper, 1963) based on the observation of inhibition clearing zone of microbial growth on an agar medium.

The bacterial inoculum was uniformly spread using sterile cotton swab on a sterile petri dish nutrient agar .The seeded plates with target test organisms were cut by sterile cork borer to make holes ( $9 \mathrm{~mm}$ in diameter). Only $0.1 \mathrm{ml}$ of each allelochemicals was transferred into each hole under aseptic conditions. The plates were kept then in a refrigerator for $1-2 \mathrm{~h}$ before incubation of each organism. The antimicrobial activity was detected as a result of clear inhibition zone around holes. Inhibition of the bacterial growth 
was measured in $\mathrm{mm}$ (SEN and Batra, 2012). The minimal inhibitory concentration was determined according to the broth macro-dilution method (concentrations ranged from 0.1 to $5 \mathrm{mg} / \mathrm{mL}$ of each allelochemicals) as recommended by (NCCLS, 1985; Ruangpan and Tendencia, 2004).

\section{Data analysis}

The experiment was arranged in factorial randomized complete block design (RCBD) with three replications where the first factor was tested substances and the second factor was the concentrations. Analysis of variance (ANOVA) was calculated using MSTAT-C computer statistical software according to Russel (1991)and Freed et al., (1991).Duncan's multiple range test (DMRT) was used as a posteriori test for multiple comparison of means (Duncans, 1955). P values of $\leq 0.05$ were considered indicative of statistical significance.

\section{RESULTS}

1. Nematoda: Data presented in Table 1 showed that the highest hatchability inhibition of nematode eggs was recorded at concentration of $100 \mu \mathrm{g} / \mathrm{ml}$ of root exudates of the three tested plants. Mean percent hatchability inhibition ranged between $87.78 \%$ in case of $A$. microcarpus to $81.15 \%$ in case of $A$. judaica. Minimal inhibition was recorded in case of S. nigrum $64.73 \%$; similar results were recorded for the mean larval mortality. Highest larval mortality percent was recorded at concentration of $100 \mu \mathrm{g} / \mathrm{ml}$ for $A$. microcarpus $87.97 \%$ and the least mortality was recorded in case of $S$. nigrum $64.13 \%$. Results of $\mathrm{LC}_{50}$ values ranged between $(40.02 \mu \mathrm{g} / \mathrm{ml}$ and $59.97 \mu \mathrm{g} / \mathrm{ml})$ in case of hatchability inhibition and between $(52.46 \mu \mathrm{g} / \mathrm{ml}$ and 
$88.50 \mu \mathrm{g} / \mathrm{ml}$ ) in case of larval mortality which confirms the degree of toxicity of each allelochemicals against egg hatching and second stage juveniles.

Data analysis revealed that the percent hatching inhibition of root knot nematode significantly increased as the concentration of root exudates of the three tested plants increased $\left(\mathrm{F}_{5,34}=5843169.13 ; \mathrm{P}<0.0001\right)$. Duncan's multiple range tests among the tested concentrations revealed highly significant difference for each paired comparison $(\mathrm{P}<0.0001)$.Results of factorial ANOVA revealed a significant interaction between the type of root exudates extracted from the three tested plants and the concentrations used on the hatchability inhibition of nematodes eggs $\left(\mathrm{F}_{10,34}=73297.39 ; \mathrm{P}<0.0001\right)$.

Highest inhibition was observed when a concentration $100 \mu \mathrm{g} / \mathrm{ml}$ of root exudates of A. microcarpus was used followed by a $100 \mu \mathrm{g} / \mathrm{ml}$ root exudates of A. judaica. Least hatchability inhibition was observed when S. nigrum was used with concentration of $12.5 \mu \mathrm{g} / \mathrm{ml}$. Statistical analysis also revealed that a concentration of $100 \mu \mathrm{g} / \mathrm{ml}$ of A. microcarpus and A. judaica caused similar larval mortality. A concentration of $12.5 \mu \mathrm{g} / \mathrm{ml}$ of $S$. nigrum caused least larval mortality. 
Table 1: Hatchability inhibition and larval mortality of $M$. incognita second stage juveniles as affected by the tested plant root exudates and $\mathrm{LC}_{\mathbf{5 0}}$ values

\begin{tabular}{|c|c|c|c|c|c|c|c|}
\hline \multirow{3}{*}{ Root exudates } & \multicolumn{6}{|c|}{$\begin{array}{c}\text { Hatching inhibition } \\
(\text { Mean } \pm \text { SD) }(\%)\end{array}$} & \multirow{3}{*}{$\begin{array}{l}\mathrm{LC}_{50} \\
(\mu \mathrm{g} / \mathrm{ml})\end{array}$} \\
\hline & \multicolumn{6}{|c|}{ Concentrations $(\mu \mathrm{g} / \mathrm{ml})$} & \\
\hline & Control & 12.5 & 25 & 50 & 75 & 100 & \\
\hline A. judaica & $0.05^{\circ}$ & $\begin{array}{c}174 \pm 0.21^{\mathrm{m}} \\
(13.05)\end{array}$ & $\begin{array}{c}306 \pm 0.25^{1} \\
(26.94)\end{array}$ & $\begin{array}{c}607 \pm 0.15^{g} \\
(58.63) \\
\end{array}$ & $\begin{array}{c}791 \pm 0.40^{d} \\
(78.00) \\
\end{array}$ & $\begin{array}{l}821 \pm 0.35^{b} \\
(81.15)\end{array}$ & 40.02 \\
\hline 4. microcarpus & $0.05^{\circ}$ & $\begin{array}{l}308 \pm 0.21^{\mathrm{k}} \\
(27.15)\end{array}$ & $\begin{array}{c}493 \pm 0.19^{j} \\
(46.63)\end{array}$ & $\begin{array}{c}704 \pm 0.45^{\mathrm{e}} \\
(68.84)\end{array}$ & $\begin{array}{c}802 \pm 0.31^{c} \\
(79.15)\end{array}$ & $\begin{array}{l}884 \pm 0.17^{\mathrm{a}} \\
(87.78)\end{array}$ & 26.87 \\
\hline S. nigrum & $0.05^{\circ}$ & $\begin{array}{c}153 \pm 0.13^{\mathrm{n}} \\
(10.84)\end{array}$ & $\begin{array}{c}308 \pm 0.47^{\mathrm{k}} \\
(27.15)\end{array}$ & $\begin{array}{l}496 \pm 0.14^{\mathrm{i}} \\
(46.94)\end{array}$ & $\begin{array}{l}567 \pm 0.16^{\mathrm{b}} \\
(54.42)\end{array}$ & $\begin{array}{c}665 \pm 0.11^{f} \\
(64.73)\end{array}$ & 59.97 \\
\hline \multicolumn{8}{|c|}{$\begin{array}{c}\text { Larval mortality } \\
\text { Mean } \pm \text { SD }(\%)\end{array}$} \\
\hline A. judaica & $2.6^{\mathrm{h}}$ & $\begin{array}{c}4.7 \pm 0.20^{\mathrm{fg}} \\
(4.43)\end{array}$ & $\begin{array}{c}11.7 \pm 0.17^{\mathrm{d}} \\
(19.19)\end{array}$ & $\begin{array}{c}21 \pm 0.25^{c} \\
(38.81)\end{array}$ & $\begin{array}{l}32 \pm 0.35^{b} \\
(62.02)\end{array}$ & $\begin{array}{c}43 \pm 0.26^{\mathrm{a}} \\
(85.23)\end{array}$ & 52.46 \\
\hline 4. microcarpus & $2.6^{\mathrm{b}}$ & $\begin{array}{l}6.3 \pm 0.14^{\text {ef }} \\
(7.81)\end{array}$ & $\begin{array}{l}13 \pm 0.31^{d} \\
(21.94)\end{array}$ & $\begin{array}{c}20 \pm 0.21^{c} \\
(36.71)\end{array}$ & $\begin{array}{c}31.3 \pm 0.65^{b} \\
(60.54)\end{array}$ & $\begin{array}{l}44.3 \pm 0.24^{\mathrm{a}} \\
(87.97)\end{array}$ & 49.89 \\
\hline S. nigrum & $2.6^{\mathrm{h}}$ & $\begin{array}{c}3 \pm 0.36^{\mathrm{gh}} \\
(2.95)\end{array}$ & $\begin{array}{c}8.2 \pm 0.07^{\mathrm{e}} \\
(9.28)\end{array}$ & $\begin{array}{c}12.2 \pm 0.10^{\mathrm{d}} \\
(19.83)\end{array}$ & $\begin{array}{c}22.1 \pm 1.37^{c} \\
(40.92)\end{array}$ & $\begin{array}{c}33.6 \pm 0.90^{\mathrm{b}} \\
(64.13)\end{array}$ & 88.50 \\
\hline
\end{tabular}

Means followed by the same letter are not significantly different, according to Duncan Multiple Range Test

Data presented in Table 2 showed that highest hatchability inhibition of nematode eggs was recorded at concentration of $100 \mu \mathrm{g} / \mathrm{ml}$ of aqueous leaf extracts of the three tested plants. Mean percent hatchability inhibition ranged between $98.84 \%$ in case of $A$. judaica to $91.68 \%$ in case of A. microcarpus. Minimal inhibition was recorded in case of S. nigrum $78.63 \%$. Similarly, the aqueous leaf extracts caused the highest larval mortality when a concentration of $100 \mu \mathrm{g} / \mathrm{ml}$ for A. judaica (100.00) was used. Least hatchability inhibition was recorded in case of $S$. nigrum (81.01).Results of $\mathrm{LC}_{50}$ values ranged between $(19.28 \mu \mathrm{g} / \mathrm{ml}$ and $38.58 \mu \mathrm{g} / \mathrm{ml})$ in case of hatchability inhibition and 
between $(22.92 \mu \mathrm{g} / \mathrm{ml}$ and $57.88 \mu \mathrm{g} / \mathrm{ml})$ in case of larval mortality which confirms the degree of toxicity of each leaf extract against egg hatching and second stage juveniles.

The percent hatching inhibition of root knot nematode significantly increases as the concentration of aqueous leaf extracts of the three tested plants increased $\left(\mathrm{F}_{5}, 34=4309132.30 ; \mathrm{P}<0.0001\right)$. Duncan's multiple range tests among the tested concentrations revealed highly significant difference for each paired comparison $(\mathrm{P}<0.0001)$. Results of factorial ANOVA revealed a significant interaction between the aqueous leaf extracts from the three tested plants and the concentrations used on the hatchability inhibition of nematodes eggs $\left(\mathrm{F}_{10,34}=33770.92 ; \mathrm{P}<0.0001\right)$.

Highest inhibition was observed when a concentration of $100 \mu \mathrm{g} / \mathrm{ml}$ of aqueous leaf extract of $A$. judaica was used followed by a $100 \mu \mathrm{g} / \mathrm{ml}$ aqueous leaf extracts of A. microcarpus. Least hatchability inhibition was observed when $S$. nigrum was used with concentration of $12.5 \mu \mathrm{g} / \mathrm{ml}$. Statistical analysis also revealed that a concentration of $100 \mu \mathrm{g} / \mathrm{ml}$ of $A$. judaica caused the highest larval mortality. In addition, the concentration of $12.5 \mu \mathrm{g} / \mathrm{ml}$ of $S$. nigrum caused the least larval mortality 
Table 2: Hatchability inhibition and larval mortality of $M$. incognita second stage juveniles as affected by the tested plant leaf extracts and $\mathrm{LC}_{\mathbf{5 0}}$ values.

\begin{tabular}{|c|c|c|c|c|c|c|c|}
\hline \multirow{3}{*}{ Leaf extract } & \multirow{2}{*}{\multicolumn{6}{|c|}{$\begin{array}{c}\text { Hatching inhibition } \\
\text { Mean } \pm \text { SD }(\%)\end{array}$}} & \multirow{3}{*}{$\begin{array}{l}\mathrm{LC}_{50} \\
(\mu \mathrm{g} / \mathrm{ml})\end{array}$} \\
\hline & & & & & & & \\
\hline & Control & 12.5 & 25 & 50 & 75 & 100 & \\
\hline A. judaica & $0.05^{p}$ & $\begin{array}{c}429 \pm 0.70^{\mathrm{m}} \\
(39.89)\end{array}$ & $\begin{array}{c}564 \pm 1.33^{j} \\
(54.10)\end{array}$ & $\begin{array}{l}826 \pm 1.35^{\mathrm{d}} \\
(81.68)\end{array}$ & $\begin{array}{c}876 \pm 1.78^{c} \\
(86.94)\end{array}$ & $\begin{array}{l}989 \pm 1.30^{\mathrm{a}} \\
(98.84)\end{array}$ & 19.28 \\
\hline A. microcarpus & $0.05^{\mathrm{p}}$ & $\begin{array}{c}266 \pm 1.47^{14} \\
(22.73)\end{array}$ & $\begin{array}{c}532 \pm 1.93^{\mathrm{k}} \\
(50.73)\end{array}$ & $\begin{array}{l}688 \pm 1.72^{g} \\
(67.15)\end{array}$ & $\begin{array}{c}806 \pm 1.67^{\mathrm{e}} \\
(79.57)\end{array}$ & $\begin{array}{l}921 \pm 1.31^{b} \\
(91.68)\end{array}$ & 27.33 \\
\hline S. nigrum & $0.05^{\mathrm{P}}$ & $\begin{array}{c}248 \pm 1.19^{\circ} \\
(20.84)\end{array}$ & $\begin{array}{c}434 \pm 0.59^{1} \\
(40.42)\end{array}$ & $\begin{array}{c}589 \pm 1.05^{\mathrm{i}} \\
(56.73)\end{array}$ & $\begin{array}{c}642 \pm 1.25^{\mathrm{h}} \\
(62.31)\end{array}$ & $\begin{array}{l}797 \pm 1.34^{\mathrm{f}} \\
(78.63)\end{array}$ & 38.58 \\
\hline \multicolumn{8}{|c|}{$\begin{array}{c}\text { Larval mortality } \\
\text { Mean } \pm \text { SD }(\%)\end{array}$} \\
\hline A. judaica & $2.6^{1}$ & $\begin{array}{l}14.4 \pm 1.18^{\mathrm{h}} \\
(24.89)\end{array}$ & $\begin{array}{l}26.8 \pm 0.62^{f} \\
(51.05)\end{array}$ & $\begin{array}{c}37.6 \pm 1.12^{d} \\
(73.83)\end{array}$ & $\begin{array}{l}48.3 \pm 1.52^{\mathrm{ab}} \\
(96.41)\end{array}$ & $\begin{array}{l}50 \pm 1.49^{\mathrm{a}} \\
(100.00)\end{array}$ & 22.92 \\
\hline 4. microcarpus & $2.6^{1}$ & $\begin{array}{c}4.6 \pm 0.61^{\mathrm{k}} \\
(5.06)\end{array}$ & $\begin{array}{c}11.4 \pm 1.66^{\mathrm{i}} \\
(19.83)\end{array}$ & $\begin{array}{c}20 \pm 1.94^{g} \\
(36.70)\end{array}$ & $\begin{array}{c}40.2 \pm 1.17^{c} \\
(78.90)\end{array}$ & $\begin{array}{c}47.2 \pm 1.60^{\mathrm{b}} \\
(93.67)\end{array}$ & 43.99 \\
\hline S. nigrum & $2.6^{1}$ & $\begin{array}{c}3.3 \pm 0.55^{\mathrm{k}} \\
(1.50) \\
\end{array}$ & $\begin{array}{c}9.2 \pm 0.80^{\mathrm{j}} \\
(13.50) \\
\end{array}$ & $\begin{array}{c}19.3 \pm 1.81^{g} \\
(34.59) \\
\end{array}$ & $\begin{array}{c}33.2 \pm 1.38^{e} \\
(64.13) \\
\end{array}$ & $\begin{array}{c}41.6 \pm 1.51^{\mathrm{c}} \\
(81.01) \\
\end{array}$ & 57.88 \\
\hline
\end{tabular}

Means followed by the same letter are not significantly different according to Duncan Multiple Range Test.

2- Bacteria: The antibacterial activity of crude root exudates (Table 3) showed that A. microcarpus inhibited the bacterial growth of the three tested bacterial species. The inhibition zone diameter of A. microcarpus root exudates ranged between 23 and $27 \mathrm{~mm}$ and its minimum inhibitory concentration (MIC) values ranged between 1.2 and $1.5 \mathrm{mg} / \mathrm{ml}$. The root exudates of A. judaica and S.nigrum showed no bactericidal effects on the gram- negative bacteria studied.

Data given in Table 4 demonstrated that the crude leaf extract of $A$. judaica showed the maximum bactericidal activity against the three studied bacterial species. A. judaica leaf extract inhibits the growth of bacteria with 
inhibition zone diameter ranging between 26 and $29 \mathrm{~mm}$. Also, $A$. microcarpus extract showed good bactericidal activity with mean inhibition zone diameter ranging between 15 and19 mm, while the lowest antibacterial activity was observed when $S$. nigrum extract was used (inhibition zone ranged between 6 and $10 \mathrm{~mm}$ ).

The high antibacterial activity had low MIC values while low antibacterial activity gave high MIC values. Results showed that the highest MIC value was detected for A. judaica leaf extract $(0.25$ to $0.45 \mathrm{mg} / \mathrm{ml})$, while the minimum MIC value was detected for S. nigrum leaf extract (3.5 to $4.5 \mathrm{mg} / \mathrm{ml}$ ) which represented the weakest bactericidal effect.

Table 3: Antibacterial effect and minimum inhibitory concentration (MIC) of crude root exudates against the three tested bacteria species.

\begin{tabular}{|c|c|c|c|}
\hline \multirow{3}{*}{ Root exudates } & \multicolumn{3}{|c|}{ Mean diameter of inhibition zone $(\mathrm{mm} \pm$ SD) } \\
\hline & \multicolumn{3}{|c|}{ Bacteria } \\
\hline & E. carotovora & X. campestris & R. solanacearum \\
\hline A. judaica & - & - & - \\
\hline A. microcarpus & $27 \pm 0.10$ & $25 \pm 0.15$ & $23 \pm 0.25$ \\
\hline S. nigrum & - & - & - \\
\hline \multicolumn{4}{|c|}{$\mathrm{MIC}(\mathrm{mg} / \mathrm{ml})$} \\
\hline A. judaica & - & - & - \\
\hline A. microcarpus & 1.5 & 1.4 & 1.2 \\
\hline S. nigrum & - & - & - \\
\hline
\end{tabular}


Table 4: Antibacterial effect and minimum inhibitory concentrations (MIC) of crude leaf extracts against the three tested bacteria species.

\begin{tabular}{|c|c|c|c|}
\hline \multirow{3}{*}{ Leaf extracts } & \multicolumn{3}{|c|}{ Mean diameter of inhibition zone (mm \pm SD) } \\
\cline { 2 - 4 } & \multicolumn{3}{|c|}{ Bacteria } \\
\cline { 2 - 4 } & E. carotovora & X. campestris & R. solanacearum \\
\hline \hline A. judaica & $29 \pm 0.26$ & $27 \pm 0.20$ & $26 \pm 0.47$ \\
\hline A. microcarpus & $19 \pm 0.22$ & $20 \pm 0.21$ & $15 \pm 0.25$ \\
\hline S. nigrum & $10 \pm 0.15$ & $7 \pm 0.17$ & $6 \pm 0.23$ \\
\hline \multicolumn{3}{|c|}{$\mathrm{MIC}(\mathrm{mg} / \mathrm{ml})$} \\
\hline A. judaica & 0.45 & 0.35 & 0.25 \\
\hline A. microcarpus & 2.5 & 1.7 & 4.0 \\
\hline S. nigrum & 4 & 3.5 & 4.5 \\
\hline
\end{tabular}

\section{DISCUSSION}

Our results indicated that the aqueous leaf extracts of the three studied plants was more potent than the root exudates of the same plants against the root knot nematodes and plant pathogenic gram-negative bacteria.

In the present study a $100 \mu \mathrm{g} / \mathrm{ml}$ aqueous leaf extract of A. judaica revealed it was the most effective against $\mathrm{M}$. incognita egg hatchability inhibition and second stage juvenile (J2) mortality. Korayem et al., (1993) proved that the exposure to standard extract of Artemisia absinthium for $72 \mathrm{~h}$ caused reduction in the number of active Meloidogyne incognita by $100 \%$ and reduction in the egg hatching by $98.7 \%$. In addition to Costa et al., 2003 showed that the ethanolic rhizome extract of Artemisia vulgaris at concentration $50 \mathrm{mg} / \mathrm{ml}$ inhibited 100\% Meloidogyne megadora egg hatching and at concentration $55.67 \mathrm{mg} / \mathrm{ml}$ caused $50 \%$ second stage juvenile mortality, both in a dose-dependent manner, D'Addabbo et al., 2013 reported that aqueous extract of Artemisia annua was toxic to $M$. incognita juveniles 
where it caused more than $90 \%$ mortality and significant reduction of egg hatchability at $500 \mu \mathrm{g} / \mathrm{ml}$ after $24 \mathrm{~h}$. The differences in lethal concentration and doses reported in the present study might be attributed to differences in the plant and nematode species used as well as differences in extraction method.

A $100 \mu \mathrm{g} / \mathrm{ml}$ of aqueous leaf extract of Asphodelus microcarpus was less potent than Artemisia judaica as it significantly reduced egg hatchability of Meloidogyne incognita by $92 \%$ and significantly increased larval mortality by 95\%. A. sativumwas reported to possess nematicidal effect against Meloidogyne sp. (Gupta and Sharmaj, 1993; Zasada et al., 2002) In addition, (Ahmed et al., 2016) reported that the aqueous whole plant extracts of Asphodelus tenuifolius caused Meloidogyne javanica mortality and egg masses reduction.

Aqueous leaf extracts of $S$. nigrum was the least effective extract against M. incognita egg hatchability inhibition and J2 mortality. Different species of Solanum plant showed similar effects on nematodes. (Dias et al., 2012; Correia, 2014)

A. judaica leaf extract was the most effective extract against the three bacterial species investigated as it caused the highest zone inhibition and MIC. These results corroborate with those recorded by Badawy and Abdelgalil, (2014), where they reported that the MIC of Artemisia judaica oil against Erwinia carotovora was 550mg/l. Also, Massiha et al., (2013) proved that Artemisia аппиа leaf oil showed antibacterial activity with inhibition zone diameter ranging between $(18-28 \mathrm{~mm})$.Present studies indicated that 
Asphodelus microcarpus leaf extracts demonstrated moderate bactericidal activity. In the same trend, other reports have addressed the antibacterial effect of Asphodelus sp. on the gram negative bacteria and recommended their use as a bio-control agents of plant bacterial diseases(Dangi et al., 2013;Eddine et al., 2015)Our results showed the weak bactericidal activity of S. nigrum aqueous leaf extracts and these are quite similar to findings of Doss et al., (2009) who reported that MIC of the tannins isolated from Solanum trilobatum against tested bacteria ranged between $1-4 \mathrm{mg} / \mathrm{ml}$ and showed bacterial growth inhibition with zone diameter ranged from 7 to $13 \mathrm{~mm}$

\section{CONCLUSION}

In conclusion, the leaf extracts of $A$. judaica has an effective nematicidal activity against root knot nematode by exhibiting some toxic compounds which cause reduction in egg hatching and death of second stage juveniles. Moreover, the leaf extracts of the A. judaica showed the highest antibacterial activity against gram negative bacteria. Therefore, the leaf extracts of the $A$. judaica is strongly recommended for root knot nematode and plant pathogenic gram negative bacteria management. These plant extracts should also be tested against other parasitic nematodes. Allelopathy offers safe solutions in pest management; in the long run it would be a luminous direction to proceed in order to develop a bioactive pesticide using the allelochemicals. 


\section{REFERENCES}

Abbott, W.S. (1925): A method of computing the effectiveness of an insecticide. Journal of Economic Entomology, 18, 265-267.

Ahmad, I.; Saifullah; Ahmad, M.; Khan, L.; Abbas, A. and Ali, R. (2016): Organic management of root-knot nematodes with non-host weed Asphodelus tenuifolius extracts. Journal of Entomology and Zoology Studies, 4, 501-508.

Aissani, N., Tedeschi, P., Maietti, A., Brandolini, V., Garau, V.L. and Caboni,P. (2013):Nematicidal activity of allylisothiocyanate from horseradish Armoracia rusticana roots against Meloidogyne incognita. Journal of Agricultural and Food Chemistry, 61, 47234727.

Akyazi, F. (2014): Effect of some plant methanol extracts on egg hatching and juvenile mortality of root-knot nematode Meloidogyne incognita. American Journal of Experimental Agriculture, 4, 1471-1479.

Badawy, M.E.I. and Abdelgaleil, S.A.M. (2014): Composition and antimicrobial activity of essential oils isolated from Egyptian plants against plant pathogenic bacteria and fungi. Industrial Crops and products, 52, 776-782.

Balah, M.A. (2015): Allelopathic effects of Bindweed Convolvulus Arvensis L. root exudates on plants and soil micro flora. Egyptian journal of desert research, 65, 35-53.

Balah, M.A. and Nassar, I.M. (2011): Allelopathic constituents from Abutilon theophrasti aerial parts to other Weeds .Research journal of agriculture and biological sciences, 7, 243-250.

Cheng, F. and Cheng, Z. (2015): Research progress on the use of plant allelopathy in agriculture and the physiological and ecological mechanisms of allelopathy. Front plant science, 6, 1-16.

Cooper, K.E. (1963): The theory of antibiotic inhibition zone. In analytical microbiology, (F. Kavanagh, Ed.), Academic Press, New York, 1, pp.13-30. 
Correia, M.C.C.P. (2014): Nematicidal activity of Solanum nigrum and S. sisymbriifolium extracts against the root- lesion nematode Pratylenchus goodeyi and its effects on infection and gene expression. Doctorate in biological science, Universidade da Madeira.

Costa, S.D.S.D.R.; Santos, M.S.N.A. and Ryan, M.F. (2003): Effect of Artemisia vulgaris rhizome extracts on hatching, mortality, and plant infectivity of Meloidogyne megadora. Journal of Nematology, 35, 437-442.

Danahap, L.S. and Wonang, D.L. (2016): Antinematicidal efficacy of root exudates of some crotalaria species on Meloidogyne incognita (root-knot nematode) (kofoid and white) chitwood isolated from infected lycopersicumesculentum (Tomato) plant. International Journal of Scientific \& Technology Research, 5, 79-84.

Dangash, A.; Ram, M.; Niranjan, R.;Bharillya, A.;Misra, H.;Pandya, N. and Jain, D.C. (2015): In vitro selection and hormonal regulation in cell culture of Artemisia annua L. plant. JSM cell\& Developmental Biology, 3, 1013, 1-7.

Dangi, A.S.; Aparna, M.S.; Yadav, J.P.; Arora, D.R. and Chaudhary, U. (2013): Antimicrobial potential of Asphodelus tunifolius (CAV).Journal of Evolution of Medical and Dental Sciences, 2, 5663-5667.

D’Addabbo, T.; Carbonara, T.; Argentieri, M.P.; Radicci,V.; Leonetti,P; Villanova,L. and Avato,P.(2013):Nematicidal potential of Artemisia апnиа and its main metabolites. European Journal Plant Pathology, 137, 295-304.

Dias, M.C.; Conceição, I.L.; Abrantes, I. and Cunha, M.J. (2012): Solanumsisym briifolium - a new approach for the management of plant parasitic nematodes. European Journal of Plant Pathology, $133,171-179$.

Doss, A.; Mubarack, H.M. and Dhanabalan, R. (2009): Antibacterial activity of tannins from the leaves of Solanum trilobatum Linn. Indian Journal of Science and Technology, 2, 41-43. 
Duncans, D.B. (1955): Multiple range test and multiple F test. Biometrics, 11, $1-42$.

Eddine, L.S., Segni, L. and Ridha, O.M. (2015): In vitro Assays of the Antibacterial and Antioxidant Properties of Extracts from Asphodelus tenuifolius Cav and its Main Constituents: A Comparative study. International Journal of Pharmaceutical and Clinical Research, 7, 119-125.

Finney, D.J. (1971): Probit Analysis 3rd edition Cambridge University Press London.

Freed, R.; Eisensmith, S.P.; Goetz, S.; Reicosky, D.; Smail, V.W. and Wolberg, P. (1991): MSTAT-C: a software program for the design, management, and analysis of agronomic research experiments. East Lansing: Michigan State University.

Gupta, R. and Sharmaj, N.K. (1993): A study of the nematicidal activity of allicinan active principle in garlic, Allium sativum L., against root-knot nematode, Meloidogyne incognita (Kofoid and White, 1919) Chitwood, 1949. International Journal of Pest Management, 39, 390-392.

Hussey, R.S. and Barker, K.R. (1973): A comparison of methods of collecting inoculum of Meloidogyne spp. including a new technique. Plant Disease Reporter, 57, 1925-1928.

Inderjit, H.K. and Mukerji, K.G. (eds.) (2006): Allelochemicals: biological control of plant pathogens and diseases, Vol. 2, 208.

Jones, J.T.; Haegeman, A.; Danchin, E.G.; Gaur, H.S.; Helder, J.; Jones, M.G.; Kikuchi,T.; Manzanilla-López, R.; Palomares-Rius, J.E.; Wesemael, W.M. and Perry, R.N.(2013): Top 10 plant-parasitic nematodes in molecular plant pathology. Molecular Plant Pathology.14, 946-61.

Kannan, V.R. and Bastas,K.K. (2015): Sustainable approaches to controlling plant pathogenic bacteria. International Standard Book.CRC press.New York. 
Kayani, M.Z.; Sarwar,G. and Muhammad, S. (2001): Control of root-knot nematode Meloidogyne incognita on tomato plants by using root extracts of plants. Journal of Agriculture in the Tropics and Subtropics, 102, p. $143-146$.

Korayem, A.M., Hasabo, S.A. and Ameen, H.H., (1993): Effects and mode of action of some plant extracts on certain plant parasitic nematodes. Anzeiger fur Schadlingskunde, Pflanzenschutz, Umweltschutz, $66,32-36$.

Lu, Y.; Sun, L. and Shi, W., (2015): Collection of root exudates from Duckweed. Bio-Protocol, 5, 1-5.

Massiha, A.; MajidKhoshkholgh-Pahlavian, M.;Issazadeh, K.;Bidarigh,S. and Zarrabi,S. (2013): Antibacterial activity of essential oils and plant extracts of Artemisia annua L. in vitro. Zahedan Journal of Research In Medical Sciences, 15, 14-18.

Inderjit and Mukerji, K.G (ed.) (2006): Allelochemicals: biological control of plant pathogens and diseases Vol. 2.

Murashige, T. \& Skoog, F. (1962): A revised medium for rapid growth and bioassays with tobacco tissue cultures. Physiologia Plantarum, 15,473-497.

NCCLS, National Committee for Clinical Laboratory Standards (1985): Approved standard M7-A. Methods for dilution antimicrobial susceptibility tests for bacteria that grow aerobically.

Ruangpan, L. and Tendencia, E.A. (2004): Laboratory manual of standardized methods for antimicrobial sensitivity tests for bacteria isolated from aquaculture. Southeast Asian Fisheries Development Center, Aquaculture Department, Iloilo, Philippines. 3, 31-55.

Russel, D.F. (1991): MSTAT-C, Director Crop and soil sciences department.Michigan state university. USA.

Sen, A. and Batra, A., (2012): Evaluation of antimicrobial activity of different solvent extracts of medicinal plant: Melia azedarach L. International Journal of Current Pharmaceutical Research, 4, 67-73. 
Sodaeizadeh, H. and Hosseini, Z. (2012): Allelopathy an environmentally friendly method for weed control. International Conference on Applied Life Sciences, Turkey.387-392.

Tang, C.S. and Young, C.C., (1982): Collection and identification of allelopathic compounds from the undisturbed root system of bigalta limpograss Hemarthria altissima. Plant Physiology, 69, $155-160$.

Wu, H.; Haig,T.; Pratley,J.; Lemerle,D. and An, M. (2000):Distribution and exudation of allelochemicals in wheat Triticum aestivum. Journal of Chemical Ecology, 26, 2141-2154.

Zasada, I.A.; Ferris, H. and Zheng, L. (2002): Plant sources of chinese herbal remedies: laboratory efficacy, suppression of Meloidogyne javanica in soil, and phytotoxicity assays. Journal of Nematology 34, 124-129. 


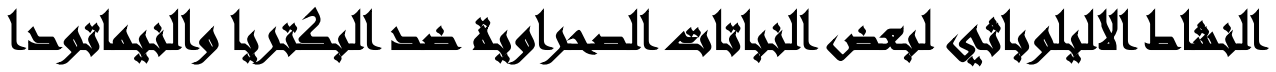 المهرغة اللنهايت}

[r]

عبد الرحمن جمال الدين عبد الرحمن(')- حنان احمد اسماعيل هاشم(؟) هالة عبد الحميد قاسم(")

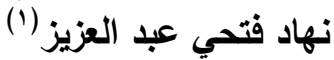

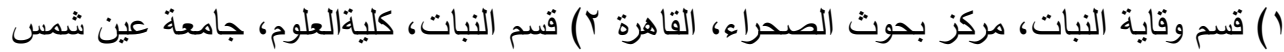

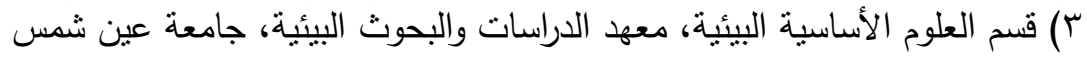

\section{المستخليك}

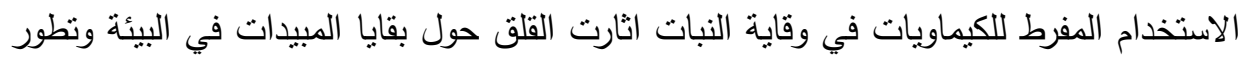

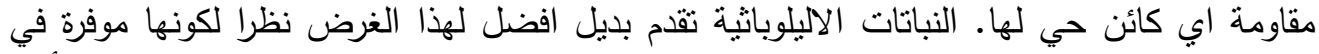

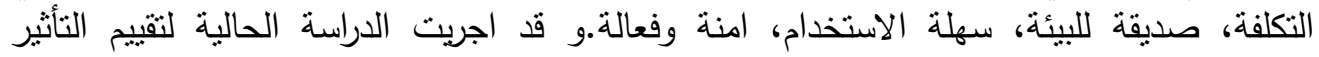

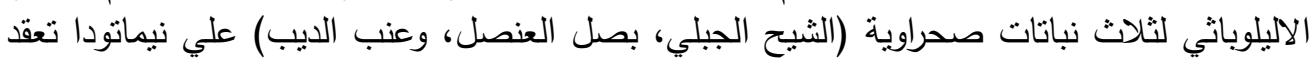
الجذور Meloidogyne incognita) وثناث سلاتلات بكتريا ممرضة للنبات (Erwinia carotovora, Xanthomonas campestris and Ralestonia solanacearum)

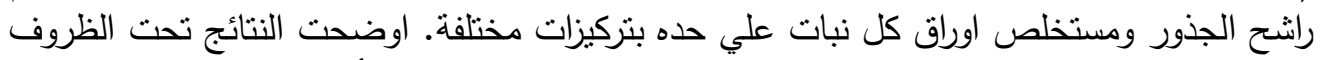

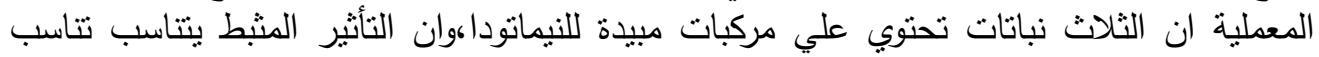

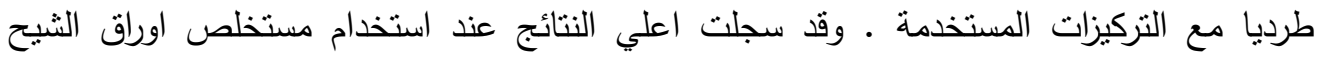

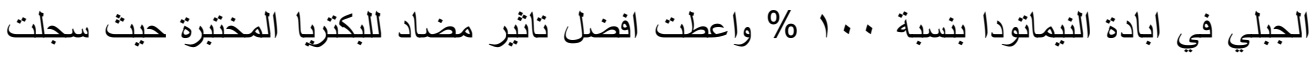

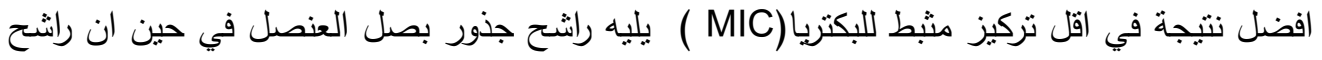

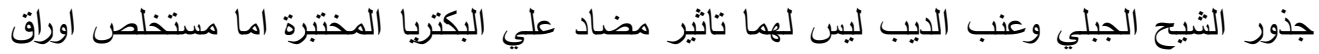

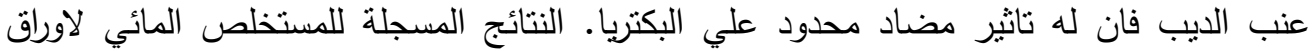

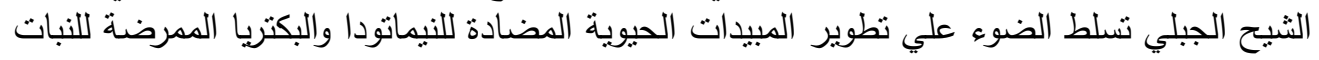

